\title{
Performance Index of Natural Stones-GFRP Hybrid Structures
}

\author{
Luca Sorrentino, Costanzo Bellini, Wilma Polini, Sandro Turchetta \\ University of Cassino and Southern Lazio, Department of Civil and Mechanical Engineering, Italy \\ luca.sorrentino@unicas.it, bttp:/ /orcid.org/0000-0002-5278-7357 \\ costanzo.bellini@unicas.it, bttp:/ / orcid.org/0000-0003-4804-6588 \\ wilma.polini@unicas.it, bttp://orcid.org/0000-0002-6839-3889 \\ sandro.turchetta@unicas.it, bttp://orcid.org/0000-0002-8365-8910
}

\begin{abstract}
Natural stone is a material that presents durableness over time and high aesthetic characteristic, but it is brittle and its tensile strength is significantly lower than compressive one: these peculiarities must be taken into account for material usage; in fact, for applications requiring high flexural and tensile strength, as thin sections or long spans, the particular mechanical behavior of the natural stone constitutes an issue to be overcome.

A solution to the above mentioned problem is presented in the present paper: a natural stone tile is reinforced by bonding a sandwich structural laminate made of composite materials. In such manner, a double result is obtained: the mechanical strength increment and the and the tile specific weight decrement. In particular, two different types of sandwich structures, made of glass/epoxy laminates and honeycomb or foam core, were bonded to the lower surfaces of marble and granite tiles; then, 3-point bending tests were carried out on specimens extracted from the produced hybrid tiles. A performance index, considering both strength and weight of tiles, was introduced and the comparison with specimens extracted from traditional unreinforced tiles demonstrated that the considered reinforcement increases the structural characteristics of stone tiles up to an order of magnitude.
\end{abstract}

KEYwORDS. Natural stones; Glass/epoxy sandwich laminate; 3-point bending test; Structural behavior improvement.

\section{OPEN ACCESS}

Citation: Sorrentino, L., Bellini, C., Polini, W. and Turchetta, S., Performance Index of Natural Stones-GFRP Hybrid Structures, Frattura ed Integrità Strutturale, 46 (2018) 285-294.

Received: 22.06 .2018

Accepted: 08.08 .2018

Published: 01.10.2018

Copyright: (C) 2018 This is an open access article under the terms of the CC-BY 4.0, which permits unrestricted use, distribution, and reproduction in any medium, provided the original author and source are credited.

\section{INTRODUCTION}

$\mathrm{F}$ or a long time, construction and in building furniture use natural stone. Only recently, the aesthetic properties of the stone are exploited to decorate the environments. All these applications are limited by the brittle nature and the consequent defects of the stone. In fact, the strength of stone in tension is considerably less than its strength in compression, the compressive strength of a rock exceeds its tensile strength by one to three orders of magnitude typically. This disparity limits the use of stone for long spans or thin sections, where tensile and flexural strength capacity is required. 
The durability and the strength of stone are affected by mechanical and chemical weathering processes. The atmosphere, water, dissolved salts, acid rain and temperature fluctuations act as agents of decay, inflicting visible damage to stone as a decay, as demonstrated by Winkler [1]. Cohen and Monteiro [2] showed that limestone and granite are affected by weathering agents and are particularly susceptible to superficial dissolution caused by carbon dioxide (CO2), sulfur dioxide (SO2) and nitric acid (NOx) dissolved in water as acid rain. It is evident that the weathering results in a loss of strength in natural stone.

Reinforcement provides stone members with flexural strength required for use in long spans, columns and slabs. However, in some cases, reinforced stone may fail to perform to its desired capacity because of faulty design, use of inferior materials, poor construction practices and insufficient maintenance. If such a problem occurs early in a structure's service life, repair and strengthening of the concrete sections may be more favorable than replacement or reconstruction of the failing members.

At the beginning of the second half of the last century, the use of external steel reinforcing to strengthen existing concrete bridges and buildings was investigated by researchers in South Africa and France. Thin steel plates were bonded with epoxy to the tension face of concrete beams to provide additional local stiffness. Subsequently, Mays [3] applied this technique to reinforce concrete members in Europe, the United Kingdom, Japan, New Zeland, South Africa and the United States. Since steel plates are readily available and relatively inexpensive, repair of structures by externally bonded reinforcement is an attractive alternative to replacement. However, corrosion of the external metal plate remains a problem.

A wide variety of civil engineering applications sees the introduction of fibre-reinforced polymers (FRPs). Neale [4] found these materials to be particularly attractive for applications involving the strengthening and rehabilitation of existing structures. Composite materials were proposed as a corrosion-resistant alternative to external steel reinforcement of concrete members. Iyer et al. [5] used sheets of graphite fibers in an epoxy matrix to strengthen cracked concrete beams in an existing bridge. Also, Saadatmanesh and Ehsani [6] showed that glass fiber composites, well bonded with epoxy to concrete beams, double the ultimate capacity of the beams also employed to increase strength and ductility with encouraging results in terms of mechanical behavior and cost effectiveness. Recently it was investigated by Sisti et al. [7] and Aiello et al. [8] a new type of reinforcement for historic masonry buildings made by recycled old stone or bricks with GFRP grits, that demonstrated to improve the bending capacity of the structure.

External composite reinforcement was infrequently applied to natural stone, as demonstrated by Kurtis and Dharan [9]. To determine the effect of external reinforcement on the load-carrying capacity of two types of stone, 3-point bend tests were performed on marble and Travertine marble (actually a limestone) reinforced with HS carbon fibers in an epoxy matrix. The results show how the load capacity of the stone may be increased of about 5-10 times.

In a previous work, Polini et al. [10] investigated the use of external composite reinforcement on natural stone. It involved the production of a hybrid structure "natural stone/composite" very thin, the use of less expensive composite materials, such as glass fiber, and the comparison between two natural stones that are largely used for decorative application, marble and granite. The results demonstrated that the load capacity of the stone can be increased by a factor of 7 and 6 for granite and marble respectively. In another work, Bellini et al. [11] created a new hybrid structure, in which the thin laminate made of composite material was substituted with a sandwich structure.

In this work, sandwich structural laminates based on composite materials are used as external reinforcement both to increase the mechanical resistance and to decrease weight of natural stone. High strength glass/epoxy laminates were bonded to the lower surfaces of marble and granite beams, and 3-point bend tests were performed on both reinforced and unreinforced specimens. Such reinforcement is useful to increase low initial tensile strength or to restore strength lost by weathering. An increase in strength can result in the use of longer spans and thinner sections, decreasing dead load. Therefore, the use of external composite reinforcement of natural stone in application such as exterior cladding, flooring, countertops, and desktops can result in weight saving and possible cost saving.

The materials and the methods to produce the specimens are deeply described in the next sections; then, the test to mechanically characterize the stone-composite sandwich specimens are deeply discussed and the obtained results are presented and analyzed.

\section{MATERIALS AND METHODS}

I $\mathrm{n}$ this work, the new hybrid material was constituted by a sandwich structural laminate in composite materials glued to a stone tile. Two kinds of sandwiches were considered: the first one was self-produced by gluing two composite skins to a DIAB Divinycell P60 core, the second one was a commercial sandwich of Hexcel Corporation, that is 
called Fibrelam ${ }^{\circledR}$ Grade 5.

The first core material chosen for the core was the DIAB Divinycell P60 panel, that is made of a recyclable closed cell thermoplastic foam. It is addressed to public transport, industrial applications and wind applications, since it offers excellent FST properties (fire and toxicity of fumes), resistance to high temperatures, good thermal insulation and low water absorption. It also offers good mechanical properties, such as excellent resistance to chemical agents and a very low density of $60 \mathrm{~kg} / \mathrm{m}^{3}$. This core is compatible with any type of resin, polyester, vinylester, epoxy and it can be used with most prepregs because it resists up to the temperature of $150{ }^{\circ} \mathrm{C}$, so there are no problems for the prepreg oven polymerization. It was used a panel of $8 \mathrm{~mm}$ thickness. The composite skins were constituted by glass fiber/epoxy matrix prepreg fabric. The composite fabric consisted of fibers woven at [0/90]; thirteen fabrics were overlapped and cured at a temperature of $125^{\circ} \mathrm{C}$ for 90 minutes by means of vacuum bagging in autoclave to obtain a board thickness of about 2 $\mathrm{mm}$, so the total thickness of the sandwich structure was $12 \mathrm{~mm}$. Composite material density is $1850 \mathrm{~kg} / \mathrm{m}^{3}$; moreover, this material has a compressive strength of $650 \mathrm{MPa}$ and a tensile strength of $1750 \mathrm{MPa}$.

The other core material was the Fibrelam ${ }^{\circledR}$, that is made of unidirectional glass fiber skins with a cross pattern of thickness $0.38 \mathrm{~mm}$ glued to an aramid alveolar panel to have a total sandwich thickness of about $10 \mathrm{~mm}$. It has excellent resistance to compression $(5.5 \mathrm{MPa})$ and to impact $(4.5 \mathrm{Nm})$, that are compatible with stone application. The Fibrelam ${ }^{\circledR}$ has a remarkable stiffness, testified by a maximum deformation of $0.8 \mathrm{~mm} / \mathrm{m}$, which allows the sandwich structure to be used without any support and a flames extinguish time of 4 seconds after a 60 -second exposure; its density is $2.5 \mathrm{~kg} / \mathrm{m}^{2}$.

Perlato Royal of Coreno and Absolute Black granite were the natural stones chosen for the tiles. Perlato Royal of Coreno is characterized by a high strength to wear and to impact that together to its resistance to weather agents carried out to be used for buildings. It has a density of $2650 \mathrm{~kg} / \mathrm{m}^{3}$; it has a compressive strength of $166 \mathrm{MPa}$ and a tensile strength of 10 $\mathrm{MPa}$. The Absolute Black granite is very hard and since it is available in small volumes, it has a great commercial value. It has a density of $3030 \mathrm{~kg} / \mathrm{m}^{3}$; it has a compressive strength of $295 \mathrm{MPa}$ and a tensile strength of $27 \mathrm{MPa}$.

Two adhesives were used to bond the self-produced composite sandwich to stone tiles: the Scotch-Weld ${ }^{\mathrm{TM}}$ EC-2216 B/A Gray of $3 \mathrm{M}^{\mathrm{TM}}$ and the Scotch-Weld ${ }^{\mathrm{TM}} \mathrm{AF} 163-2 \mathrm{k}$ of $3 \mathrm{M}^{\mathrm{TM}}$. The first is an epoxy resin Scotch-Weld ${ }^{\mathrm{TM}} \mathrm{EC}-2216 \mathrm{~B} / \mathrm{A}$ Gray of $3 \mathrm{M}^{\mathrm{TM}}$, whose polymerization time is 7 days at $24^{\circ} \mathrm{C}, 2$ hours at $66^{\circ} \mathrm{C}$ and 30 minutes at $93{ }^{\circ} \mathrm{C}$. It is commonly used for composite material and it is suitable for aerospace applications. The second adhesive is a thermosetting epoxy resin Scotch-Weld ${ }^{\mathrm{TM}} \mathrm{AF} 163-2 \mathrm{k}$ of $3 \mathrm{M}^{\mathrm{TM}}$, which occurs as a veil. It polymerizes in 90 minutes at $107.2^{\circ} \mathrm{C}$.

The commercial sandwich Hexcel Fibrelam ${ }^{\circledR}$ was glued to stone only by means of the resin Scotch-Weld ${ }^{\mathrm{TM}}$ AF163-2k of $3 \mathrm{M}^{\mathrm{TM}}$, since it allows to reach the best geometrical precision in gluing, so taking full advantage of the high precision of the commercial sandwich.

All the samples manufactured are shown in Tab. 1, five repetitions were carried out for each parameter combination. After bonding to sandwich panels, each hybrid tile was cut with a diamond saw to produce samples measuring $40 \mathrm{~mm} \mathrm{x}$ $200 \mathrm{~mm}$ for 3-point bending tests.

The 3-point bend test was considered for evaluating the structural properties of the obtained samples, according to the UNI EN 12372 standard for stone products. In detail, the width of the sample should be between $25 \mathrm{~mm}$ and $100 \mathrm{~mm}$ and it has to be twice the size of the largest grain in the stone. The sample length should be six times its thickness, while the distance between the two pins that sustain the sample should be five times its thickness.

\begin{tabular}{ccc}
\hline Factor & \# levels & $\begin{array}{c}\text { Level value } \\
\text { Stone type }\end{array}$ \\
Stone thickness $[\mathrm{mm}]$ & 2 & $\begin{array}{c}\text { Coreno Perlato Royal, } \\
\text { Absolute Black Granite }\end{array}$ \\
Core type & 2 & $3,4,6$ \\
Adhesive type & 2 & $\begin{array}{c}\text { DIAB P60, } \\
\text { Fibrelam Grade 5 }\end{array}$ \\
\hline
\end{tabular}

Table 1: Experimental plan.

Process to prepare the sample with core DLAB P60 and EC-2216 adhesive

Three marble tiles and three granite tiles, whose dimensions were $200 \mathrm{~mm}$ x $200 \mathrm{~mm} \times 10 \mathrm{~mm}$, were brushed on the raw side by means of an abrasive paper and, then, they were cleaned by a cloth soaked in ethylic alcohol. The same operations were repeated on the composite laminate of $2.2 \mathrm{~mm}$ thickness, once cut through a band-saw at $205 \mathrm{~mm} \times 205 \mathrm{~mm}$. A 
panel of core DIAB P60 was cut to obtain six samples of $203 \mathrm{~mm}$ x $203 \mathrm{~mm}$, their thickness was reduced from $20 \mathrm{~mm}$ to $8 \mathrm{~mm}$ by a vertical sawing machine and, then, theirs surfaces were cleaned through a jet of compressed air. Now, the adhesive was applied on a raw side of the stone, both sides of the composite laminate and both sides of the core DIAB P60 in a uniform way (see Fig. 1). Therefore, the stone was assembled to the composite sandwich and the obtained sample was put into some clamps in order to avoid the development of air bubbles and the leak of adhesive at the interface due to the excessive pressure. The samples were polymerized at room temperature for 120 minutes and at $63^{\circ} \mathrm{C}$ into an oven for further 120 minutes.

\section{Process to prepare the sample with core DLAB P60 and AF163-2k adhesive}

Three marble tiles and three granite tiles, whose dimensions were $200 \mathrm{~mm}$ x $200 \mathrm{~mm} \times 10 \mathrm{~mm}$, were brushed on the raw side by means of an abrasive paper and, then, they were cleaned by a cloth soaked in ethylic alcohol. The same operations were repeated on the composite laminate of $2.2 \mathrm{~mm}$ thickness, once cut through a band-saw at $205 \mathrm{~mm} \times 205 \mathrm{~mm}$. A panel of core DIAB P60 was cut to obtain six samples of $203 \mathrm{~mm}$ x $203 \mathrm{~mm}$, their thickness was reduced from $20 \mathrm{~mm}$ to $8 \mathrm{~mm}$ by a milling machine and, then, theirs surfaces were cleaned through a jet of compressed air. Now, a film of adhesive was taken out the freezer and kept at room temperature for two hours. Then, it was cut at the dimensions of the tile and it was applied on the stone surface; then the composite laminate was put on the other side of the adhesive film. Another piece of adhesive was applied on the free composite laminate surface and the core DIAB P60 was put on the other side of the adhesive. A final piece of adhesive was applied to the free core surface and another composite laminate was put on the other side of the adhesive film. The obtained samples were put into a vacuum bag (see Fig. 2), previously lined with breather in order to support the vacuum distribution around the samples. The bag was sealed and the air was inhaled up to a pressure of 0.50 bar. Now, the bag was put into the oven and the temperature was increased of $4.95{ }^{\circ} \mathrm{C}$ per minute for twenty minutes, up to arrive at $135^{\circ} \mathrm{C}$; then, the temperature was kept constant for 1 hour. Finally, the oven was turned off and the bag was kept in pressure till the temperature reached $65^{\circ} \mathrm{C}$.

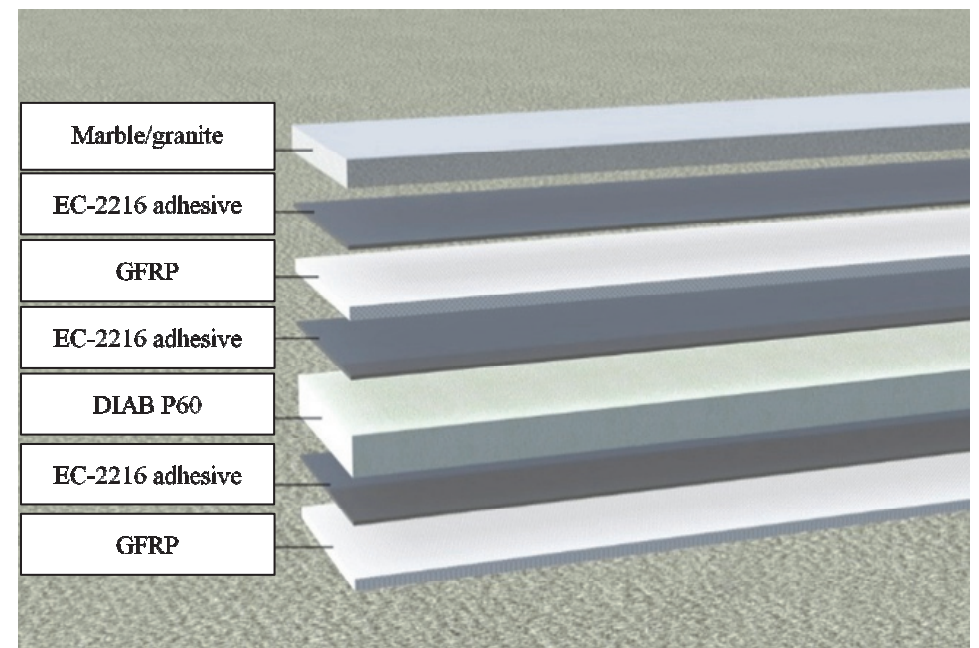

Figure 1: Sample with core DIAB P60 and EC-2216 adhesive.

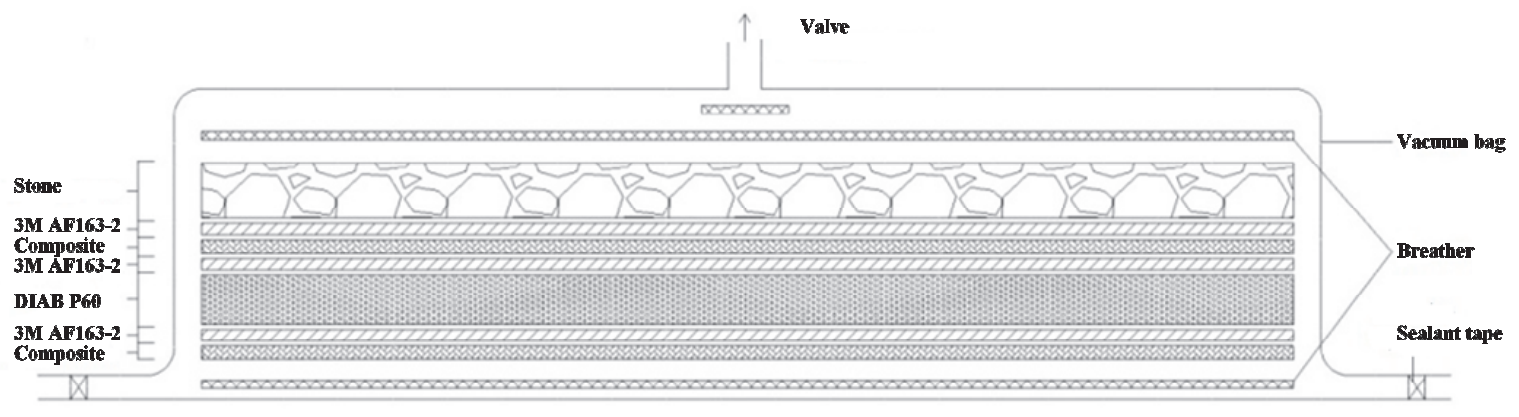

Figure 2: Process scheme for the manufacturing of sandwich structure with core DIAB P60 and AF163-2k adhesive. 
Process to prepare the sample with Fibrelam ${ }^{\circledR}$ and AF163-2k adhesive

Three marble tiles and three granite tiles, whose dimensions were $200 \mathrm{~mm}$ x $200 \mathrm{~mm} \times 10 \mathrm{~mm}$, were brushed on the raw side by means of an abrasive paper and, then, they were cleaned by a cloth soaked in ethylic alcohol. The same operations were repeated on the Hexcel Fibrelam ${ }^{\circledR}$ panels, once cut through a band-saw at $205 \mathrm{~mm}$ x $205 \mathrm{~mm}$. Now, a film of adhesive was taken out the freezer and kept at room temperature for two hours. Then, it was cut at the dimensions of the tile and it was applied on the stone surface; then the Fibrelam ${ }^{\circledR}$ panel was put on the other side of the adhesive film (see Fig. 3). The obtained samples were put into a vacuum bag (see Fig. 4), previously lined with breather in order to support the vacuum distribution around the samples. The bag was sealed and the air was inhaled up to a pressure of 0.50 bar. Now, the bag was put into the oven and the temperature was increased of $4.95{ }^{\circ} \mathrm{C}$ per minute for twenty minutes, up to arrive at $135^{\circ} \mathrm{C}$; then, the temperature was kept constant for 1 hour. Finally, the oven was off and the bag was kept in pressure till the temperature reached $65^{\circ} \mathrm{C}$.

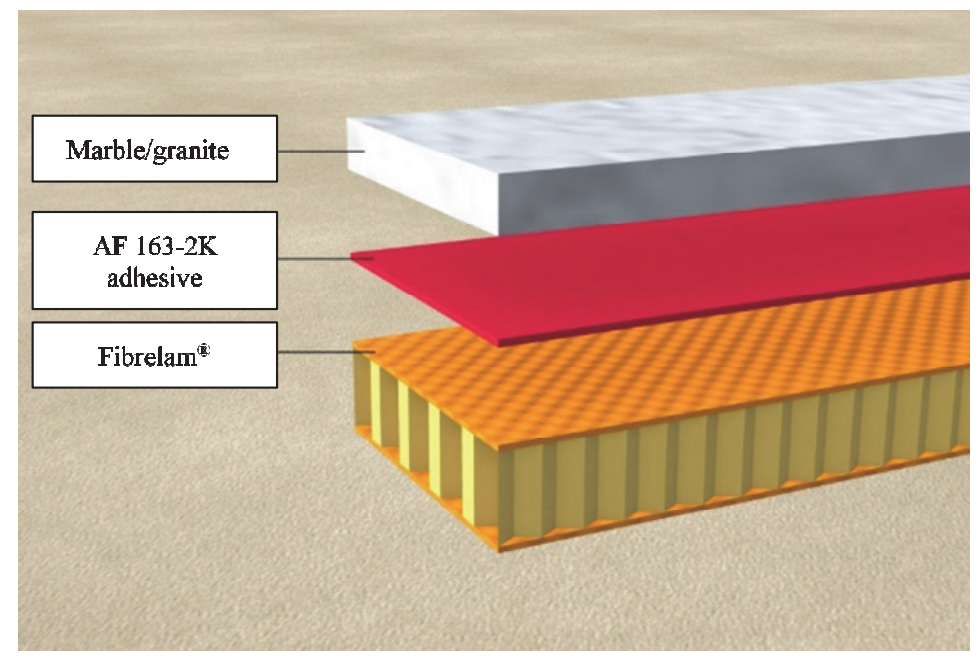

Figure 3: Sample with core Hexcel Fibrelam ${ }^{\circledR}$ and AF163-2k adhesive.

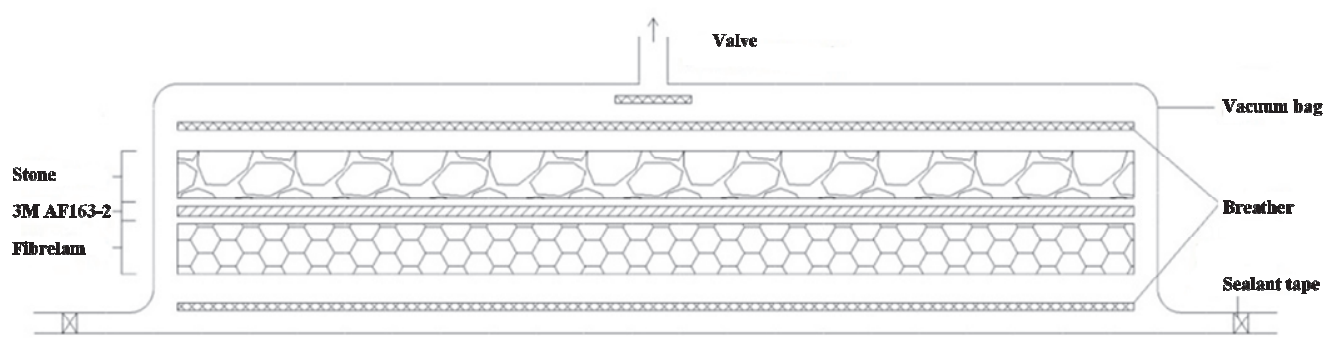

Figure 4: Process scheme for the manufacturing of sandwich structure with core Fibrelam ${ }^{\circledR}$ and AF163-2k adhesive.

\section{RESULTS DISCUSSION}

A n Instron ${ }^{\circledR}$ machine was used to perform 3-point bending test on the specimens manufactured as described above, see Fig. 5. The samples were tested in an unconditioned state at room temperature. Results from the 3point bending tests are presented in Tab. 2. Figs. 6-8 show an example of load trend vs displacement in 3-point bend test of samples with a stone tile of $3 \mathrm{~mm}$ thickness.

Three points bending tests results show that the samples with the core DIAB P60 reached an average maximum load higher than that of samples with the core Hexcel Fibrelam ${ }^{\circledR}$. Moreover, in Figs. 6-8 deflection before failure of the sample with the core Hexcel Fibrelam ${ }^{\circledR}$ is higher than that of the samples reinforced with the core DIAB P60, that makes more rigid the sample.

If AF163-2k adhesive is used instead of EC-2216, the samples reinforced with the core DIAB P60 show an average maximum load higher of about $0.2-0.5 \mathrm{kN}$, once fixed the stone type and thickness; this is probably due to, in addition to the best mechanical performances of the adhesive, also and above all to its uniform thickness. 
The mechanical performances of the samples increase slightly as the thickness of the stone increases, once fixed the type of stone and adhesive; this is probably due to the fact that stone is as more rigid as greater is its thickness, stiffness that limits the deflection to failure of the samples.

Among the samples with core DIAB P60 and adhesive AF163-2k that with the highest value of the average maximum load has a marble or granite thickness of $6 \mathrm{~mm}$; it presents a load to bend of about $3.9 \mathrm{kN}$ or $4.8 \mathrm{kN}$ for marble and granite respectively that is $150 \%$ or $60 \%$ more than the corresponding sample in marble or granite only (see Tab. 2).

Figs. 6-8 show how the deflection before failure of the samples with granite is higher than those with marble, that is due to the greater resistance and homogeneity of the granite compared to the marble.
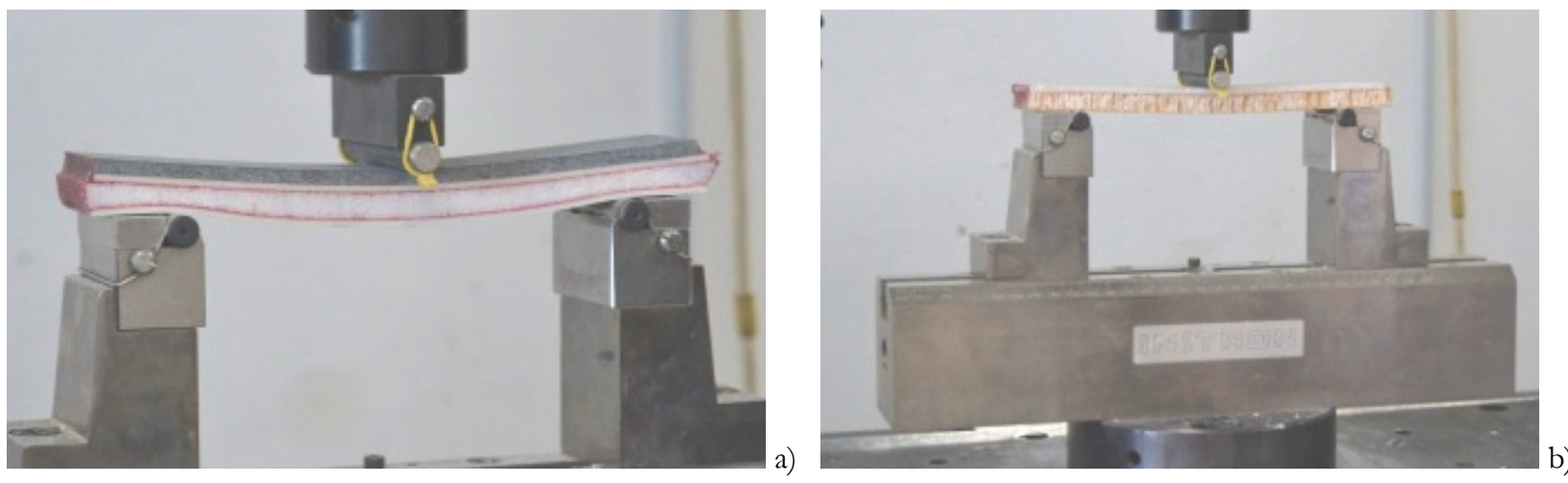

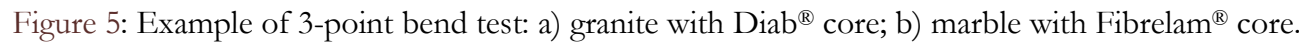

Tab. 3 reports the weights, with the same total thickness, of the sandwich structure samples compared to the same ones in marble or granite. As can be seen from the table, the lightest samples have a core of Hexcel Fibrelam ${ }^{\circledR}$, since this panel has a weight of $2.5 \mathrm{~kg} / \mathrm{m}^{2}$ compared to $9.5 \mathrm{~kg} / \mathrm{m}^{2}$ of the sandwich structure constituted by the DIAB P60 core and the two glass fiber laminates.

The lightest sample, that has a marble tile of $3 \mathrm{~mm}$ thickness and a Hexcel Fibrelam ${ }^{\circledR}$ core, has a weight of $11.12 \mathrm{~kg} / \mathrm{m}^{2}$ that is about 3 times lower than that of the same sample of marble. The heaviest panel, that has a granite tile of $6 \mathrm{~mm}$ thickness and a DIAB P60 core, weights $28.14 \mathrm{~kg} / \mathrm{m}^{2}$ compared to $54.54 \mathrm{~kg} / \mathrm{m}^{2}$ of the same sample in granite only.

Therefore, considering the ratio between flexural load and weight, that is called Performance Index PI, it can be seen that the sandwich structures have a PI from 2 to 5 times higher than that of the stone sample with the same thickness; in particular, the sandwich structure with Hexcel Fibrelam ${ }^{\circledR}$ panel and a marble tile of $3 \mathrm{~mm}$ thickness has a PI equal to $138.35 \mathrm{~N}^{*} \mathrm{~m}^{2} / \mathrm{kg}$ compared to $30.64 \mathrm{~N}^{*} \mathrm{~m}^{2} / \mathrm{kg}$ of marble sample with the same thickness.

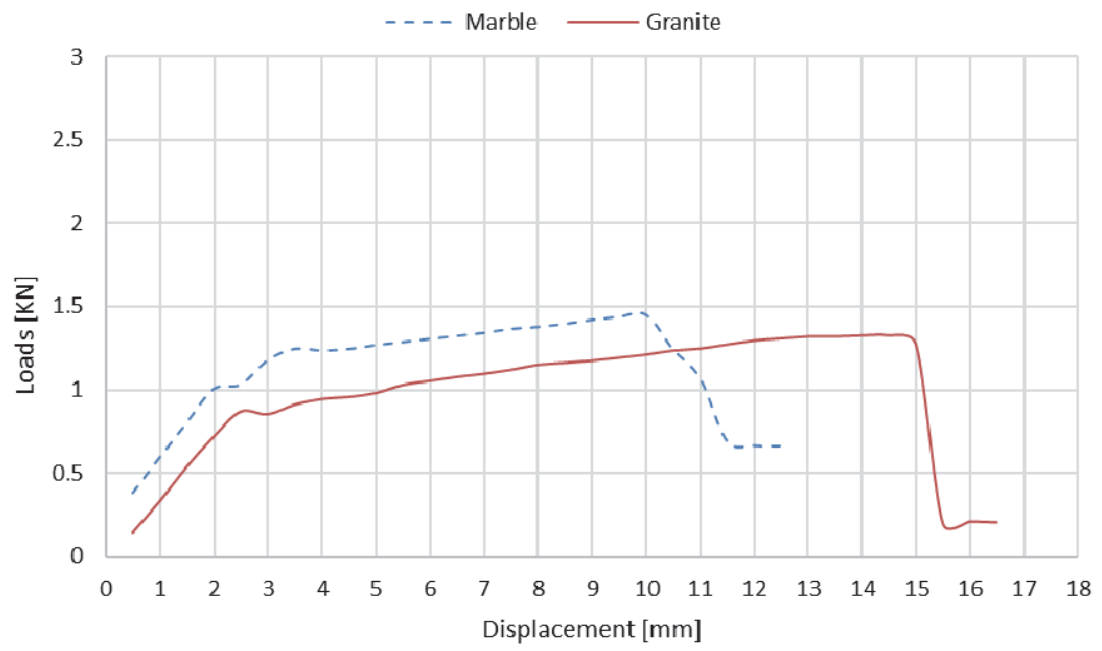

Figure 6: Trend of load vs displacement in 3-point bending test: Stone 3mm+Adhesive AF163-2k+ core Hexcel Fibrelam ${ }^{\circledR}$ core. 


\begin{tabular}{|c|c|c|c|c|c|c|c|c|}
\hline \multirow{2}{*}{$\begin{array}{l}\text { Stone } \\
\text { type }\end{array}$} & \multirow{2}{*}{ Core type } & \multirow{2}{*}{ Adhesive } & \multirow{2}{*}{$\begin{array}{c}\text { Stone } \\
\text { thickness } \\
{[\mathrm{mm}]}\end{array}$} & \multicolumn{2}{|c|}{$\begin{array}{l}\text { Loads }[\mathrm{kN}] \\
\text { hybrid panel }\end{array}$} & \multicolumn{2}{|c|}{$\begin{array}{c}\text { Loads }[\mathrm{kN}] \\
\text { stone }\end{array}$} & \multirow{2}{*}{ Difference } \\
\hline & & & & $\begin{array}{c}\text { Average } \\
\text { value }\end{array}$ & $\begin{array}{l}\text { Standard } \\
\text { Deviation }\end{array}$ & $\begin{array}{c}\text { Average } \\
\text { value }\end{array}$ & $\begin{array}{c}\text { Standard } \\
\text { Deviation }\end{array}$ & \\
\hline \multirow{3}{*}{$\begin{array}{l}\text { Perlato } \\
\text { Coreno } \\
\text { marble }\end{array}$} & \multirow{2}{*}{ DIAB P60 } & EC-2216 & 3 & 2.071 & 0.092 & 1.056 & 0.004 & $96.12 \%$ \\
\hline & & AF163-2k & 3 & 2.244 & 0.027 & 1.056 & 0.004 & $112.50 \%$ \\
\hline & Fibrelam & AF163-2k & 3 & 1.539 & 0.015 & 0.915 & 0.003 & $68.20 \%$ \\
\hline \multirow{3}{*}{$\begin{array}{c}\text { Absolute } \\
\text { Black } \\
\text { granite }\end{array}$} & \multirow{2}{*}{ DIAB P60 } & EC-2216 & 3 & 2.392 & 0.057 & 2.029 & 0.012 & $17.89 \%$ \\
\hline & & AF163-2k & 3 & 2.583 & 0.028 & 2.029 & 0.012 & $27.30 \%$ \\
\hline & Fibrelam & AF163-2k & 3 & 1.284 & 0.043 & 1.758 & 0.013 & $-26.98 \%$ \\
\hline \multirow{3}{*}{$\begin{array}{l}\text { Perlato } \\
\text { Coreno } \\
\text { marble }\end{array}$} & \multirow{2}{*}{ DIAB P60 } & EC-2216 & 4 & 2.512 & 0.026 & 1.201 & 0.004 & $109.16 \%$ \\
\hline & & AF163-2k & 4 & 3.011 & 0.024 & 1.201 & 0.004 & $150.71 \%$ \\
\hline & Fibrelam & AF163-2k & 4 & 2.110 & 0.037 & 1.050 & 0.005 & $100.79 \%$ \\
\hline \multirow{3}{*}{$\begin{array}{c}\text { Absolute } \\
\text { Black } \\
\text { granite }\end{array}$} & \multirow{2}{*}{ DIAB P60 } & EC-2216 & 4 & 3.029 & 0.017 & 2.308 & 0.013 & $31.24 \%$ \\
\hline & & AF163-2k & 4 & 3.480 & 0.050 & 2.308 & 0.013 & $50.78 \%$ \\
\hline & Fibrelam & AF163-2k & 4 & 2.335 & 0.015 & 2.019 & 0.012 & $15.62 \%$ \\
\hline \multirow{3}{*}{$\begin{array}{l}\text { Perlato } \\
\text { Coreno } \\
\text { marble }\end{array}$} & \multirow{2}{*}{ DIAB P60 } & EC-2216 & 6 & 3.275 & 0.149 & 1.520 & 0.005 & $115.46 \%$ \\
\hline & & AF163-2k & 6 & 3.905 & 0.072 & 1.520 & 0.005 & $156.91 \%$ \\
\hline & Fibrelam & AF163-2k & 6 & 2.769 & 0.024 & 1.351 & 0.003 & $104.94 \%$ \\
\hline \multirow{3}{*}{$\begin{array}{c}\text { Absolute } \\
\text { Black } \\
\text { granite }\end{array}$} & \multirow{2}{*}{ DIAB P60 } & EC-2216 & 6 & 4.372 & 0.063 & 2.921 & 0.017 & $49.67 \%$ \\
\hline & & AF163-2k & 6 & 4.797 & 0.169 & 2.921 & 0.017 & $64.22 \%$ \\
\hline & Fibrelam & AF163-2k & 6 & 2.885 & 0.032 & 2.596 & 0.019 & $11.11 \%$ \\
\hline
\end{tabular}

Table 2: Results of experimental 3-point bending tests.

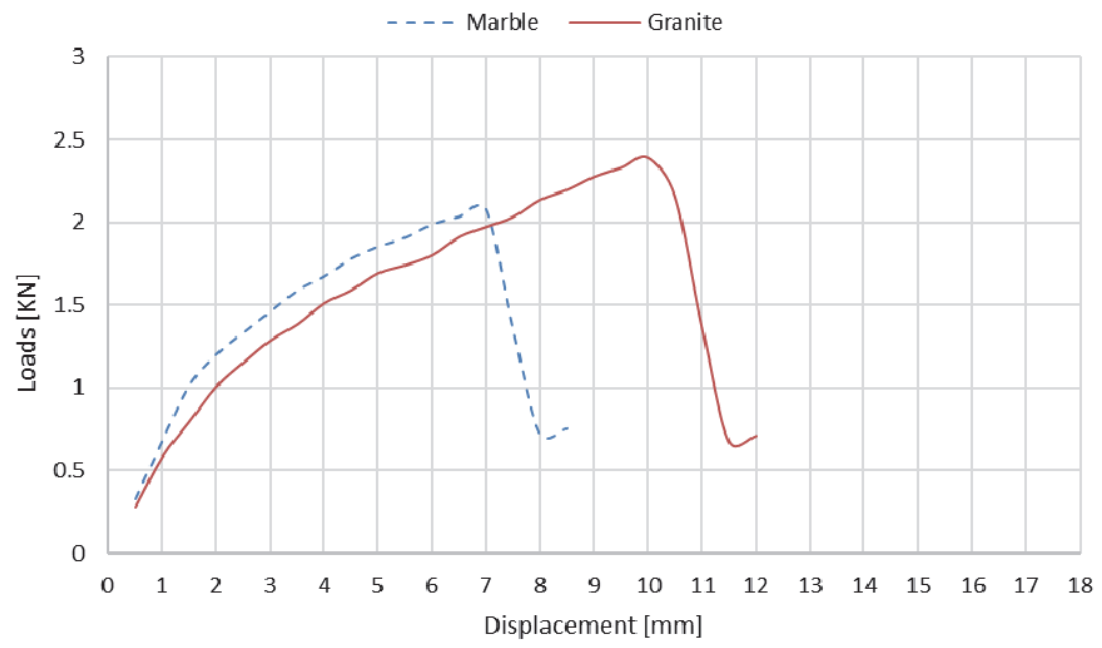

Figure 7: Trend of load vs displacement in 3-point bending test: Stone 3mm+Adhesive EC-2216+ core DIAB P60. 


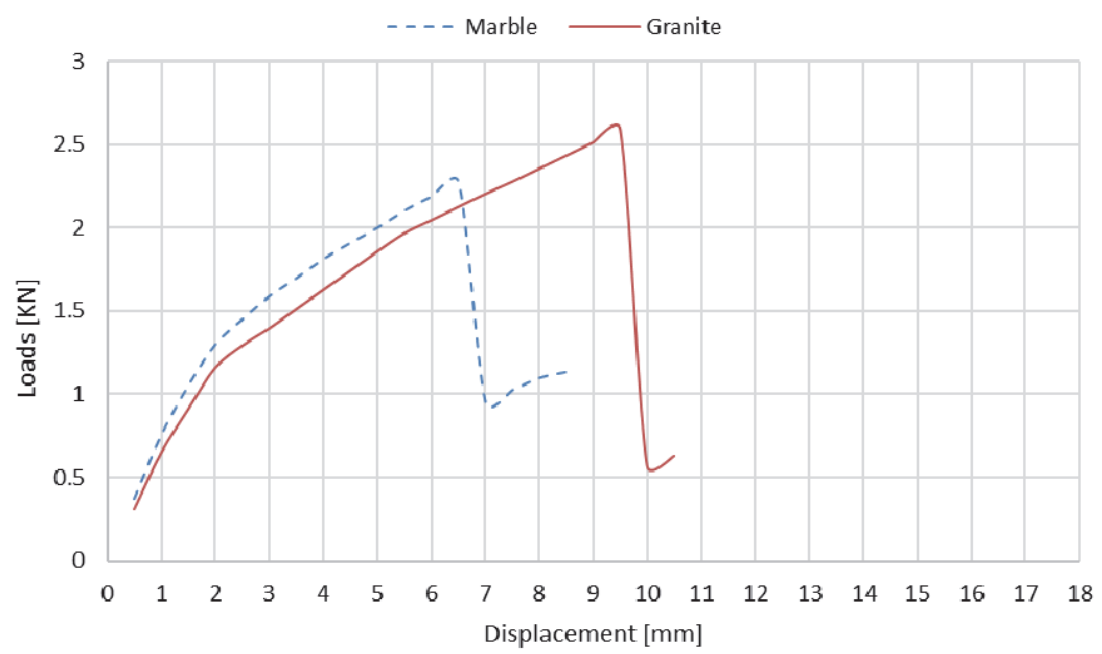

Figure 8: Trend of load vs displacement in 3-point bending test: Stone 3mm+Adhesive AF163-2k+ core DIAB P60.

\begin{tabular}{|c|c|c|c|c|c|c|c|c|c|}
\hline \multirow[b]{2}{*}{ Stone type } & \multirow[b]{2}{*}{ Core type } & \multirow[b]{2}{*}{ Adhesive } & \multirow{2}{*}{$\begin{array}{c}\text { Stone } \\
\text { thickness } \\
{[\mathrm{mm}]}\end{array}$} & \multicolumn{3}{|c|}{ Weight $\left[\mathrm{kg} / \mathrm{m}^{2}\right]$} & \multicolumn{3}{|c|}{$\mathrm{PI}\left[\mathrm{N}^{*} \mathrm{~m}^{2} / \mathrm{Kg}\right]$} \\
\hline & & & & $\begin{array}{c}\text { Hybrid } \\
\text { panel }\end{array}$ & Stone & Diff. & $\begin{array}{c}\text { Hybrid } \\
\text { panel }\end{array}$ & Stone & Diff. \\
\hline \multirow{3}{*}{$\begin{array}{l}\text { Perlato } \\
\text { Coreno } \\
\text { marble }\end{array}$} & \multirow{2}{*}{ DIAB P60 } & EC-2216 & 3 & 18.12 & 39.75 & $54.42 \%$ & 114.29 & 26.55 & $330 \%$ \\
\hline & & AF163-2k & 3 & 18.28 & 39.75 & $54.01 \%$ & 122.76 & 26.55 & $362 \%$ \\
\hline & Fibrelam & AF163-2k & 3 & 11.12 & 34.45 & $67.72 \%$ & 138.35 & 30.64 & $352 \%$ \\
\hline \multirow{3}{*}{$\begin{array}{l}\text { Absolute } \\
\text { Black } \\
\text { granite }\end{array}$} & \multirow{2}{*}{ DIAB P60 } & EC-2216 & 3 & 20.00 & 45.45 & $56.00 \%$ & 119.58 & 44.63 & $168 \%$ \\
\hline & & AF163-2k & 3 & 19.61 & 45.45 & $56.85 \%$ & 131.69 & 44.63 & $195 \%$ \\
\hline & Fibrelam & AF163-2k & 3 & 12.50 & 39.39 & $68.27 \%$ & 102.72 & 51.50 & $99 \%$ \\
\hline \multirow{3}{*}{$\begin{array}{l}\text { Perlato } \\
\text { Coreno } \\
\text { marble }\end{array}$} & \multirow{2}{*}{ DIAB P60 } & EC-2216 & 4 & 20.50 & 42.40 & $51.65 \%$ & 122.52 & 28.32 & $333 \%$ \\
\hline & & AF163-2k & 4 & 19.67 & 42.40 & $53.61 \%$ & 153.08 & 28.32 & $441 \%$ \\
\hline & Fibrelam & AF163-2k & 4 & 14.62 & 37.10 & $60.59 \%$ & 144.32 & 32.37 & $346 \%$ \\
\hline \multirow{3}{*}{$\begin{array}{l}\text { Absolute } \\
\text { Black } \\
\text { granite }\end{array}$} & \multirow{2}{*}{ DIAB P60 } & EC-2216 & 4 & 22.43 & 48.48 & $53.73 \%$ & 135.06 & 47.61 & $184 \%$ \\
\hline & & AF163-2k & 4 & 22.16 & 48.48 & $54.29 \%$ & 157.06 & 47.61 & $230 \%$ \\
\hline & Fibrelam & AF163-2k & 4 & 15.94 & 42.42 & $62.42 \%$ & 146.47 & 54.41 & $169 \%$ \\
\hline \multirow{3}{*}{$\begin{array}{l}\text { Perlato } \\
\text { Coreno } \\
\text { marble }\end{array}$} & \multirow{2}{*}{ DIAB P60 } & EC-2216 & 6 & 24.70 & 47.70 & $48.22 \%$ & 132.60 & 31.86 & $316 \%$ \\
\hline & & AF163-2k & 6 & 25.76 & 47.70 & $46.00 \%$ & 151.57 & 31.86 & $376 \%$ \\
\hline & Fibrelam & AF163-2k & 6 & 18.81 & 42.40 & $55.64 \%$ & 147.22 & 35.85 & $311 \%$ \\
\hline \multirow{3}{*}{$\begin{array}{l}\text { Absolute } \\
\text { Black } \\
\text { granite }\end{array}$} & \multirow{2}{*}{ DIAB P60 } & EC-2216 & 6 & 28.14 & 54.54 & $48.40 \%$ & 155.36 & 53.56 & $190 \%$ \\
\hline & & AF163-2k & 6 & 27.90 & 54.54 & $48.84 \%$ & 171.95 & 53.56 & $221 \%$ \\
\hline & Fibrelam & AF163-2k & 6 & 21.94 & 48.48 & $54.74 \%$ & 131.50 & 60.25 & $118 \%$ \\
\hline
\end{tabular}

Table 3: PI comparison between sandwich structure and stone. 


\section{CONCLUSIONS}

$\mathrm{I}$ $\mathrm{n}$ order to increase load-carrying capacity of natural stone, an external sandwich structural laminate in composite material can be efficiently glued to a stone tile. Among the samples with core DIAB P60 and adhesive AF163-2k that with the highest value of the average maximum stress has a marble or granite thickness of $6 \mathrm{~mm}$; it presents a load to bend of about $3.9 \mathrm{KN}$ or $4.8 \mathrm{KN}$ for marble and granite respectively that is $150 \%$ or $60 \%$ more than the corresponding sample in marble or granite only. The lightest sample, that has a marble tile of $3 \mathrm{~mm}$ thickness and a Hexcel Fibrelam ${ }^{\mathbb{B}}$ core, has a weight of $11.12 \mathrm{Kg} / \mathrm{m}^{2}$ that is about 3 times lower than that of the same sample of marble. The heaviest panel, that has a granite tile of $6 \mathrm{~mm}$ thickness and a DIAB P60 core, weights $28.14 \mathrm{Kg} / \mathrm{m}^{2}$ compared to $54.54 \mathrm{Kg} / \mathrm{m}^{2}$ of the same sample in granite only. Therefore, considering the load/weight ratio, that is called Performance Index PI, it can be seen that the sandwich structures have a PI from 2 to 5 times higher than that of the stone sample with the same thickness; in particular, the sandwich structure with Hexcel Fibrelam ${ }^{\circledR}$ panel and a marble tile of $3 \mathrm{~mm}$ thickness has a PI equal to $138.35 \mathrm{~N}^{*} \mathrm{~m}^{2} / \mathrm{Kg}$ compared to $30.64 \mathrm{~N}^{*} \mathrm{~m}^{2} / \mathrm{Kg}$ of marble sample with the same thickness.

Finally, it is possible to conclude that it is convenient to substitute tiles of natural stone of $20 \mathrm{~mm}$ or $30 \mathrm{~mm}$ thickness with thin stone tiles reinforced with a sandwich structural laminate in composite material. In this way it is possible to resolve some problems that are typical of stone, such as the difficulty of carriage and of assembly, the impossibility to obtain large tile (i.e. $3000 \mathrm{~mm} \times 1500 \mathrm{~mm}$ ), the excessive brittleness and so on. Moreover, it will be possible to apply the natural stone reinforced with composite sandwich panels to nautical and aerospace field, due to the significant reduction in weight, and, therefore, it will be possible to make precious the rooms of yacht and luxurious airplanes.

Further testing should be done to determine the optimal number of composite fiber plies required to provide adequate mechanical proprieties. Such a determination could result in cost savings and increased ductility of the reinforced stone. In addition, the use of smaller thickness of stone should be investigated. Finally, an investigation of the effect of external composite reinforcement of stones that have curved shape should be conducted.

\section{ACKNOWLEDGEMENTS}

7 he authors are grateful to eng. Adriano for his valuable research that has given rice for this work. Special thanks to Tecnavan Interiors s.r.l. (AIDA project to bring innovation in small and medium firms of Frosinone district, Italy) for providing materials and in particular to Mr M. Fiorini and Mr S. Fini.

\section{REFERENCES}

[1] Winkler, E.M (1994). Stone in architecture: properties, durability, New York, Springer-Verlag Inc.

[2] Cohen, J.M. and Monteiro, P.J.M. (1991). Durability and integrity of marble cladding: a state-of-the-art review, J. Perf Constr Fac. ASCE, 5(2), pp. 113-124. DOI: 10.1061/(ASCE)0887-3828(1991)5:2(113).

[3] Mays, G.C. (1985). Structural applications of adhesives in civil engineering, Mat. Sc. Techn., 1, pp. 937-943. DOI: $10.1179 /$ mst.1985.1.11.937.

[4] Neale, K.W. (2000). FRPs for structural rehabilitation: a survey of recent progress, Progress in Struc. Engin. Mat., 2(2), pp. 133-138 DOI: 10.1002/1528-2716(200004/06)2:2<133::AID-PSE16>3.0.CO;2-C.

[5] Iyer, S., Silvaramakrishnan, C and Atmaram, S. (1989). Testing of reinforced concrete bridges for external reinforcement. In: ASCE (Eds), Structural Material: Proceedings of 7th Annual Structural Congress, New York, USA; pp. 116-122.

[6] Saadatmanesh, H. and Ehsani, M.R. (1989). Application of fiber-composites in civil engineering. In: ASCE (Eds), Structural Material: Proceedings of 7th Annual Structural Congress, New York, USA, pp. 526-535.

[7] Sisti R., Corradi M. and Borri A. (2016). An experimental study on the influence of composite materials used to reinforce masonry ring beams, Con. Build. Mat., 122, pp. 231-241. DOI: 10.1016/j.conbuildmat.2016.06.120.

[8] Aiello, M., Micelli, F. and Valente, L. (2007). Structural Upgrading of Masonry Columns by Using Composite Reinforcements. J. Compos. Constr., 11(6), pp. 650-658. DOI: 10.1061/(ASCE)1090-0268(2007)11:6(650).

[9] Kurtis, K.E. and Dharan, C.K.H. (1997). Composite fibers for external reinforcement of natural stone, J Comp. Constr., 1(3), pp. 116-119. DOI: 10.1061/(ASCE)1090-0268(1997)1:3(116) 
[10] Polini W., Sorrentino L., Turchetta S. and Fiorini M. (2015). Polymeric composite laminate to increase the performance of natural stones, Int. J.Eng. Techn., 7(2), pp. 453-460.

[11] Bellini, C., Polini, W., Sorrentino, L., Turchetta, S. (2018). Mechanical performances increasing of natural stones by GFRP sandwich structures, Proc. Struct. Integr., 9, pp. 179-185. DOI: 10.1016/j.prostr.2018.06.028 